\title{
Effect of High Temperatures on the Microstructure of Cement Paste
}

\author{
M. A. Tantawy \\ Chemistry Department, Faculty of Science, Minia University, Minya, Egypt \\ Email: matantawy75@yahoo.com
}

How to cite this paper: Tantawy, M.A. (2017) Effect of High Temperatures on the Microstructure of Cement Paste. Journal of Materials Science and Chemical Engineering, 5, 33-48.

https://doi.org/10.4236/msce.2017.511004

Received: September 11, 2017

Accepted: November 14, 2017

Published: November 17, 2017

Copyright $\odot 2017$ by author and Scientific Research Publishing Inc. This work is licensed under the Creative Commons Attribution International License (CC BY 4.0).

http://creativecommons.org/licenses/by/4.0/

\begin{abstract}
The microstructural and compositional changes within the cement paste exposed to high temperatures were monitored by XRD, FTIR, TGA/DTA and SEM techniques to understand the nature of decomposition of C-S-H gel and the associated physicomechanical properties of thermally damaged cement paste. OPC paste (w/c ratio 0.27 ) was hydrated for 28 days then fired up to $750^{\circ} \mathrm{C}$ for 2 hours (heating rate $10^{\circ} \mathrm{C} / \mathrm{min}$ ). The relative mass percent of calcium hydrates and portlandite was estimated by calculations derived from TGA results. Beyond $450^{\circ} \mathrm{C}$, the percentage of portlandite sharply diminishes and C-S-H progressively decomposes into $\mathrm{C}_{2} \mathrm{~S}$ and $\mathrm{C}_{3} \mathrm{~S}$ until complete loss of calcium hydrates content occurs at $750^{\circ} \mathrm{C}$. An increase of the total porosity, severe loss in mechanical strength and propagation of harmful cracks occurs. The thermal shock as a result of cooling of the heated cement paste and the rehydration of lime enhance the propagation of harmful cracks.
\end{abstract}

\section{Keywords}

Cement paste, C-S-H, Portlandite, Dehydration, Microstructure

\section{Introduction}

The exposure of concrete to high temperatures induces severe microstructural changes and concrete loses its strength and durability [1]. Concrete approximately loses half of its strength at a temperature of $600^{\circ} \mathrm{C}$ and loses most of its compressive strength above $800^{\circ} \mathrm{C}$ [2]. The literature that deals with the effect of high temperatures on the properties of concrete can be divided into two categories. The first category investigates the degree of deterioration on the mechanical properties of concrete exposed to high temperatures and evaluates the fire damaged concrete by using nondestructive tools such as ultrasonic and resonance vibration techniques [3] [4]. The influence of high temperatures on the mechan- 
ical properties of concrete depends on physico-chemical properties of the concrete constituents [5] [6], temperature of exposure [7], size of the concrete structure [8], external applied loadings [9] and cooling conditions [10]. The second category investigates the microstructural changes induced in concrete exposed to high temperatures.

The deterioration of concrete exposed to high temperatures is attributed to:

1) The thermal mismatch due to the expansion of siliceous aggregate and shrinkage of cement paste matrix [11],

2) The decomposition of hydrates due to the decomposition of portlandite and C-S-H [12],

3) The coarsening of pore structure due to void formation as a result of loss of bound water [13],

4) The pore pressure effects due to buildup of vapor pressure inside closed pores [14] and,

5) Cracking that develops as a result of the rehydration of lime [15].

In literature, the following investigations were performed on cement paste after exposure to high temperatures.

1) Assessment of the structural properties of cement paste such as stiffness of cement paste by absorption capacity [11], pore structure by backscattered electron microscopy/mercury intrusion porosimetry/gas permeability techniques [15], and crack density by digital microscope [16].

2) Evaluation of the microstructural changes by XRD, DSC/TGA/DTG/DTA and SEM/EDX techniques [17]-[22].

3) Monitoring of the phase transformations by instrumental techniques [12] [23] [24].

4) Estimation of the cementitious phases [13] [25] [26] [27].

5) Estimation of the dehydration mechanisms and kinetics for decomposition of portlandite and C-S-H [28].

The major changes that occur within cement paste due to exposure to high temperatures include the decomposition of portlandite and calcium silicate hydrates [23]. There is a contradiction in the literature about the nature and types of the decomposition products of $\mathrm{C}-\mathrm{S}-\mathrm{H}$ gel which decomposes over a wide range temperature (about from $105^{\circ} \mathrm{C}$ to $1000^{\circ} \mathrm{C}$ [29]) as a result of its amorphous nature. Zhang and Ye calculated the activation energy ( $\mathrm{Ea}$ ) of the dehydration of $\mathrm{C}-\mathrm{S}-\mathrm{H}$ and portlandite by Arrhenius equation from TGA/DTG results. Eaportlandite is about $151.82 \mathrm{~kJ} / \mathrm{mol}$ whereas $\mathrm{Ea}_{\mathrm{C}-\mathrm{S}-\mathrm{H}}$ varies from 83.69 to 371.93 $\mathrm{kJ} / \mathrm{mol}$. Accordingly, the dehydration of portlandite is a single-step reaction, whereas the dehydration of C-S-H is a multi-step reaction because of its complex structure [28].

Many researchers examined the dehydration of C-S-H gel in cement paste exposed to high temperatures. According to Alonso and Fernandez, C-S-H gel dehydrates above $200^{\circ} \mathrm{C}$ to nesosilicate phase with $\mathrm{CaO} / \mathrm{SiO}_{2} \approx 2$, assimilated to a structure of $\mathrm{C}_{2} \mathrm{~S}$ but with less crystalline structure and the dehydration was completed at $750^{\circ} \mathrm{C}$ [12]. According to Stepkowska, C-S-H gel dehydrates in the 
temperature range of $110^{\circ} \mathrm{C}-450^{\circ} \mathrm{C}$ and transforms to $\mathrm{C}_{2} \mathrm{~S}$ and $\mathrm{C}_{3} \mathrm{~S}$ above $600^{\circ} \mathrm{C}$ [23]. According to Heikal, C-S-H gel dehydrates in the temperature range of $100^{\circ} \mathrm{C}-400^{\circ} \mathrm{C}$ and transforms to $\mathrm{C}_{2} \mathrm{~S}$ and $\mathrm{C}_{3} \mathrm{~S}$ at $800^{\circ} \mathrm{C}$ [24]. According to Peng, $\mathrm{C}-\mathrm{S}-\mathrm{H}$ gel started to decompose at $560^{\circ} \mathrm{C}$ and transforms to $\mathrm{C}_{2} \mathrm{~S}$ and $\mathrm{C}_{3} \mathrm{~S}$ at $800^{\circ} \mathrm{C}[13]$.

According to Ghosh et al., the rehydration of dehydrated phases that take place in the fired cement pastes after cooling at moist air, that together with the changes in volume, and mass may lead to an additional increase in the porosity of cement paste and enhances the formation of additional cracks [30]. Many researchers reported that there are many factors that control the extent of deterioration caused by $\mathrm{CaO}$ rehydration such as the rate of water absorption [31] and the initial mineralogy of Portland cement, (i.e. primarily the amount alumina phases [32]). The estimation of rehydrating portlandite can be used as tracers for determining the heating history of concrete exposed to high temperatures [25]. Many researchers investigated the effect of high temperatures and rehydration on the mechanical properties of blended cement pastes. According to Vysvaril et al., the cement paste with the addition of granulated blast furnace slag has the best resistivity to high temperatures; however, the limestone cement paste shows better mechanical properties after rehydration process [33]. In contrast, the rehydration process promotes the reformation of C-S-H gel from the nesosilicate phase as well as the recrystallization of calcite, portlandite and ettringite phases [12]. In the other hand, it was reported that the rehydration of the anhydrous phases is accompanied by partial recovery of the mechanical properties of the fire-exposed concrete structure [34] and [35]. The rehydration process displays cementitious behavior similar to that of the calcium silicates present in Portland cement, developing strength and thus potentially enabling the production of construction materials. According to Shui et al., the addition of fly ash and Portland cement to preheated recycled concrete can significantly enhance its rehydrated strength [36]. Serpell and Lopez developed reactivated cementitious materials from recycling of hydrated cement paste wastes as alternative binders of high environmental value [37].

The aim of this contribution is to monitor the microstructure and phase changes of cement paste exposed to high temperatures up to $750^{\circ} \mathrm{C}$ by XRD, FTIR, TGA/DTA and SEM techniques and to correlate the phase changes with the physico-mechanical properties of the thermally damaged cement paste. What differentiate this work from that of others is that the approximate percentage of residual calcium hydrates ( $\mathrm{C}-\mathrm{S}-\mathrm{H}$, ettringite and calcium aluminate hydrates) in cement pastes fired at a given temperature relative to that in unfired cement paste was estimated.

\section{Materials and Experimental Techniques}

Cement paste was prepared from OPC [CEM I 42.5] using water/cement ratio equals to 0.27 . Cement paste was cast in $2 \mathrm{~cm}^{3}$ stainless steel cubic moulds at about $100 \%$ relative humidity for 24 hours. Cement paste was cured for 28 days 
under water to enhance hydration of the cement paste before being subjected to the fire experiment. The compressive strength of the cement pastes was measured using a manual compressive strength machine according to ASTM designation [38].

The loss in compressive strength $(L)$ was calculated according to [39]:

$$
L=\left(l-S_{f} / S\right) \times 100
$$

where $S_{f}$ is the compressive strength after exposure to high temperature, and $S$ is the compressive strength before exposure to high temperature.

Termination of the hydration of cement paste was performed using a domestic microwave oven [40]. The bulk density of unfired cement pastes was measured according to the Archimedes principle [41]. Bulk density was determined as the weight of the cement paste divided by its volume. Where the volume of cement paste is calculated from the weight difference between cement in air and suspended in water. Each measurement was carried out on three similar specimens of the same testing time. The total porosity of unfired cement pastes was measured as described elsewhere [42]. The total porosity was calculated from the values of bulk density as well as the free and total water contents of the cement paste. Cement pastes were dried at $105^{\circ} \mathrm{C}$ for 24 hours and fired at $300^{\circ} \mathrm{C}, 450^{\circ} \mathrm{C}$, $600^{\circ} \mathrm{C}$ and $750^{\circ} \mathrm{C}$ for 2 hours in a muffle furnace with a heating rate of $10^{\circ} \mathrm{C} / \mathrm{min}$. The heating curve was illustrated Figure 1 . The desired temperature was maintained for 2 hours. At the end of the heating period, the specimens were removed from the furnace and were cooled down to room temperature in a desiccator. The weight loss of fired cement pastes was measured as the percentage of the weight loss based on weight after firing. The bulk density and total porosity of fired cement pastes were measured according to the ISO 5018-1983 [43]. XRF analysis was performed by Philips PW $1606 \mathrm{x}$-ray fluorescence spectrometer. XRD analysis was performed by Philips x-ray diffractometer PW 1370 with $\mathrm{Ni}$ filtered $\mathrm{CuKa}$ radiation (1.5406 $\AA$ ). The semi-quantitative phase determination was estimated by measuring the areas of representative peaks, using X'Pert HighScore Plus software and JCPDS-ICDD data base. The standard deviation was $\pm 5 \%$. FTIR analysis was performed by spectrometer Perkin Elmer FTIR System Spectrum X in the range $400-4000 \mathrm{~cm}^{-1}$. SEM analysis was performed by Jeol-Dsm $5400 \mathrm{LG}$ apparatus. TGA/DrTGA/DTA were performed by Shimadzu Corporation thermo analyzer with DTG-60H detector with $10^{\circ} \mathrm{C} / \mathrm{min}$ heating rate from the room temperature up to $1000^{\circ} \mathrm{C}$, under air
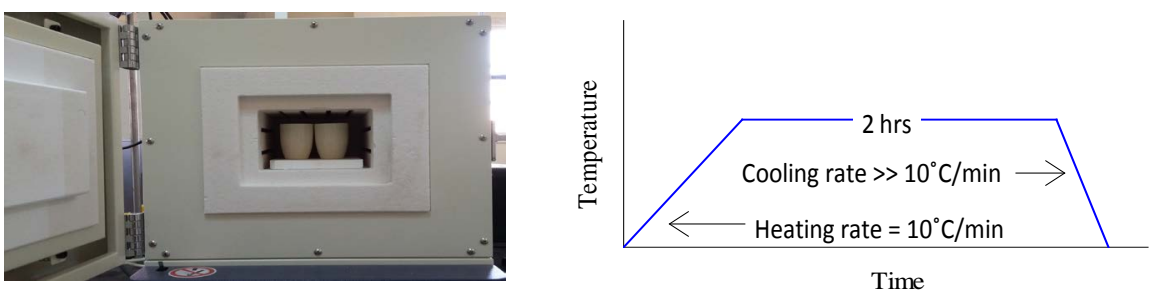

Figure 1. The muffle furnace and heating profile. 
atmosphere at $40 \mathrm{ml} / \mathrm{min}$ flow rate, the hold time at the appropriate temperature is zero.

The percentage of portlandite $(P)$ in the unfired and fired cement pastes was calculated for the following reaction $\left(\mathrm{Ca}(\mathrm{OH})_{2} \rightarrow \mathrm{CaO}+\mathrm{H}_{2} \mathrm{O}\right)$ as [44]:

$$
P=f \cdot \Delta w t
$$

where; $F$ is the mole ratio $\mathrm{Ca}(\mathrm{OH})_{2} / \mathrm{H}_{2} \mathrm{O}$ equal 4.11 and, $\Delta w t$ is the weight loss in TGA curve due to the dehydration of portlandite.

It not possible to calculate the percentage of calcium hydrates (C-S-H, ettringite and calcium aluminate hydrates) by the above method because calcium hydrates has unknown structure and able to incorporate guest ions [45]. Alternatively, it was assumed that the relative proportions of calcium hydrate species (C-S-H, ettringite and calcium aluminate and aluminosilicate hydrates) are the same for a particular cement paste under the same condition. Hence, the rate of dehydration of calcium hydrates in the fired cement pastes will be constant. Accordingly, the approximate percentage of residual calcium hydrates in cement pastes fired at a given temperature relative to that in unfired cement paste can be estimated as follows:

Relative percentage of calcium hydrates $(r)=(\Delta w t f \Delta w t) \times 100$

Percentage of calcium hydrates decomposition $=r-100$

where: $\Delta w t$ is the weight loss in TGA curve corresponding to dehydration of calcium hydrates for unfired cement paste, and $\Delta w t f$ is the weight loss corresponding to dehydration of calcium hydrates for cement paste fired at a given temperature.

\section{Results and Discussion}

Figure 2 illustrates the weight loss of cement pastes that were fired at $300^{\circ} \mathrm{C}$ $750^{\circ} \mathrm{C}$. Weight loss increases with temperature. Weight loss that occurs at $300^{\circ} \mathrm{C}$ may be due to the evaporation of capillary water from macro capillary pores, evaporation of gel water from gel pores of cement paste and partial dehydration of C-S-H [46]. Weight loss that occurs at $450^{\circ} \mathrm{C}$ may be due to the dehydration of portlandite as evidenced from DTA results (Figure 3). Weight loss that occurs at $600^{\circ} \mathrm{C}-750^{\circ} \mathrm{C}$ is due to the dehydration of residual portlandite and C-S-H as well as decomposition of calcite [21].

Figure 4 illustrates the bulk density and total porosity of unfired cement paste and that were fired at $300^{\circ} \mathrm{C}-750^{\circ} \mathrm{C}$. Bulk density sharply decreases at $300^{\circ} \mathrm{C}$ then decreases very slowly at the higher temperatures. Total porosity decreases at $300^{\circ} \mathrm{C}$ then increases at the higher temperatures. With rising temperature up to $300^{\circ} \mathrm{C}$, the vapor produced from the evaporation of capillary water and dehydration of calcium hydrates accumulates while the total porosity decreases. Hence, an internal vapor pressure builds up inside the low permeable cement paste. Under this hydrothermal condition, vapor pressure encourages the hydration of unhydrated cement phases and formation of additional hydration products as well as fills some of open pores of cement paste [12]. The decrease of bulk 


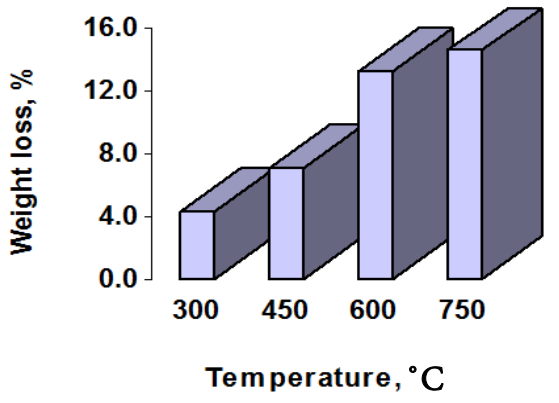

Figure 2. Weight loss of cement pastes fired at $300^{\circ} \mathrm{C}-750^{\circ} \mathrm{C}$.

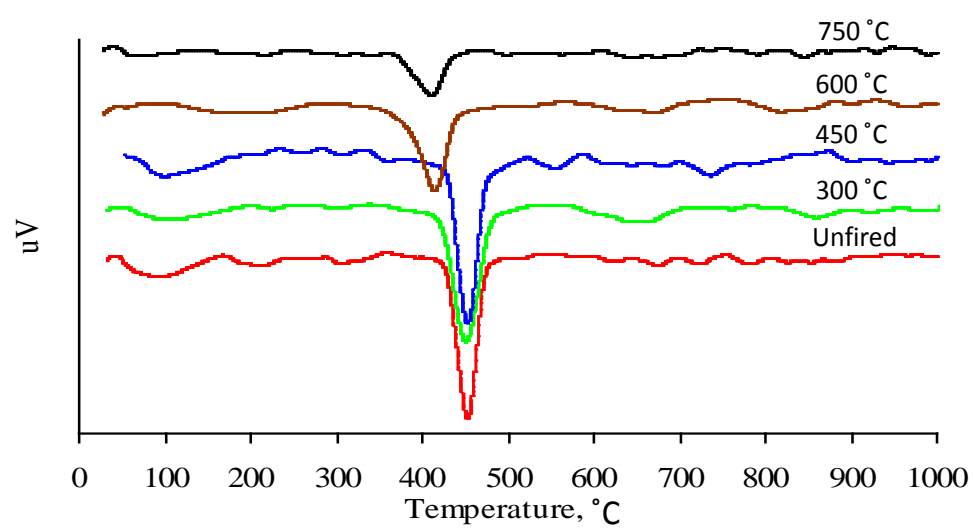

Figure 3. DTA thermograms of cement pastes fired at $300^{\circ} \mathrm{C}-750^{\circ} \mathrm{C}$.

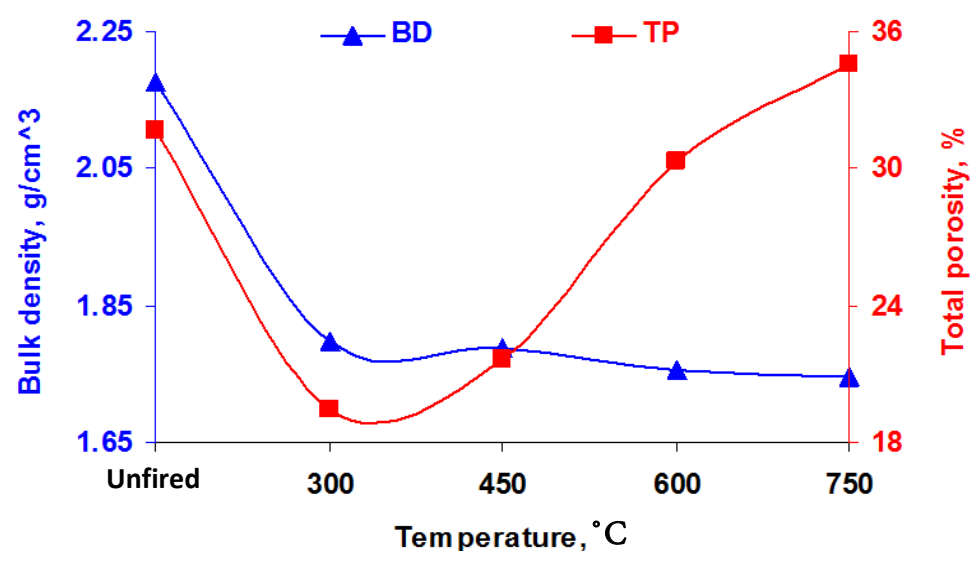

Figure 4. Bulk density and total porosity of cement pastes fired at $300^{\circ} \mathrm{C}$ $750^{\circ} \mathrm{C}$.

density leads to the suggestion that the hydration products that was formed under this hydrothermal condition have low density compared to that formed at ambient temperatures. With rising temperature above $300^{\circ} \mathrm{C}$, the decomposition of C-S-H and portlandite opens the pore system of cement paste and increases the total porosity [47].

Figure 5 illustrates the strength loss of cement paste fired at $300^{\circ} \mathrm{C}-750^{\circ} \mathrm{C}$. The loss in compressive strength may be considered as an important measure of 


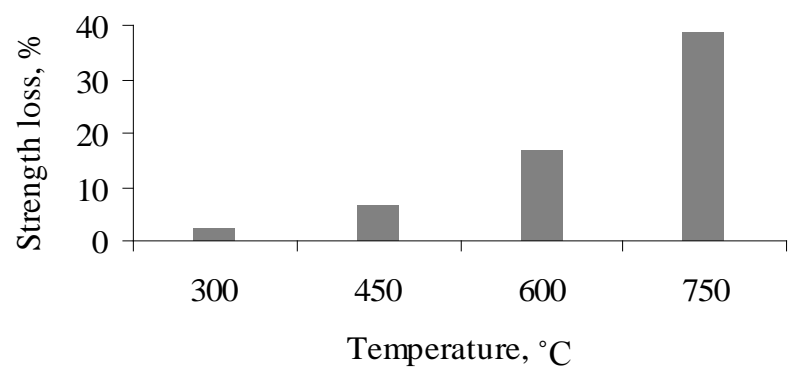

Figure 5. Strength loss of cement pastes fired at $300^{\circ} \mathrm{C}-750^{\circ} \mathrm{C}$.

the degree of damage to concrete exposed to high temperatures. The strengthening of unfired cement paste results from the coexistence of the amorphous and crystalline C-S-H that binds particles into cohesive mass [48]. With rising temperature, a negligible and limited strength loss was observed at $300^{\circ} \mathrm{C}$ and $450^{\circ} \mathrm{C}$ then the strength loss markedly increases at the higher temperatures. This indicates that beyond the critical temperature of $450^{\circ} \mathrm{C}$ the decomposition of C-S-H markedly progresses [13].

Figure 6 illustrates the FTIR spectra of cement paste fired at $300^{\circ} \mathrm{C}-750^{\circ} \mathrm{C}$. In the case of OPC, the wide band at around $923-930 \mathrm{~cm}^{-1}$, which is attributed to the $v_{3}(\mathrm{Si}-\mathrm{O})$ asymmetric stretching vibrations of alite was shifted to higher wavenumbers (around $978 \mathrm{~cm}^{-1}$ ) as cement hydration progressed. In the case of the unfired cement sample, the formation of C-S-H gel was accompanied by a gradual weakening of the $v_{4}(\mathrm{O}-\mathrm{Si}-\mathrm{O})$ absorption band at $520 \mathrm{~cm}^{-1}$ which is attributed both to unhydrated alite and belite. The bands at 1144 and $1107 \mathrm{~cm}^{-1}$ which are attributed to $v_{3}$ asymmetric stretching vibrations of the sulfate group $\left(\mathrm{SO}_{4}^{2-}\right)$ in gypsum were replaced with a new band at around $1115 \mathrm{~cm}^{-1}$ that attribute to $v_{3}$ vibrations of $\mathrm{SO}_{4}^{2-}$ in ettringite [49]. In the case of fired cement pastes, the FTIR results can be utilized to monitor the phase changes due to exposure to high temperatures. Table 1 summarizes the relative intensity of the characteristic absorption bands given in Figure 6. C-S-H progressively decreases due to its decomposition above $450^{\circ} \mathrm{C}$. This agrees with the results of strength loss. $\mathrm{C}_{3} \mathrm{~S}$ and $\mathrm{C}_{2} \mathrm{~S}$ increase with rising temperature as a result of the decomposition of C-S-H. Portlandite decreases due to its dehydration around $450^{\circ} \mathrm{C}$. Traces of portlandite were detected at $600^{\circ} \mathrm{C}-750^{\circ} \mathrm{C}$ due to the rehydration of lime [12]. Calcite decomposes at $750^{\circ} \mathrm{C}$.

Figure 7 illustrates the TGA thermograms of cement paste fired at $300^{\circ} \mathrm{C}$ $750^{\circ} \mathrm{C}$. The first weight loss in the temperature range $25^{\circ} \mathrm{C}-320^{\circ} \mathrm{C}$ is attributed to the dehydration of C-S-H, ettringite and calcium aluminate hydrates [54]. The temperature at which these compounds lose water depends upon the $\mathrm{CaO} / \mathrm{SiO}_{2}$ ratio in the hydrated cement matrix [26]. The second and third weight loss in the temperature ranges $350^{\circ} \mathrm{C}-550^{\circ} \mathrm{C}$ and $650^{\circ} \mathrm{C}-800^{\circ} \mathrm{C}$ are attributed to the dehydration of portlandite and decarbonation of calcite respectively [55]. A significant amount of calcite was detected in all of the hydrated samples is attributed to the limestone filler commonly added to OPC [56]. The relative 


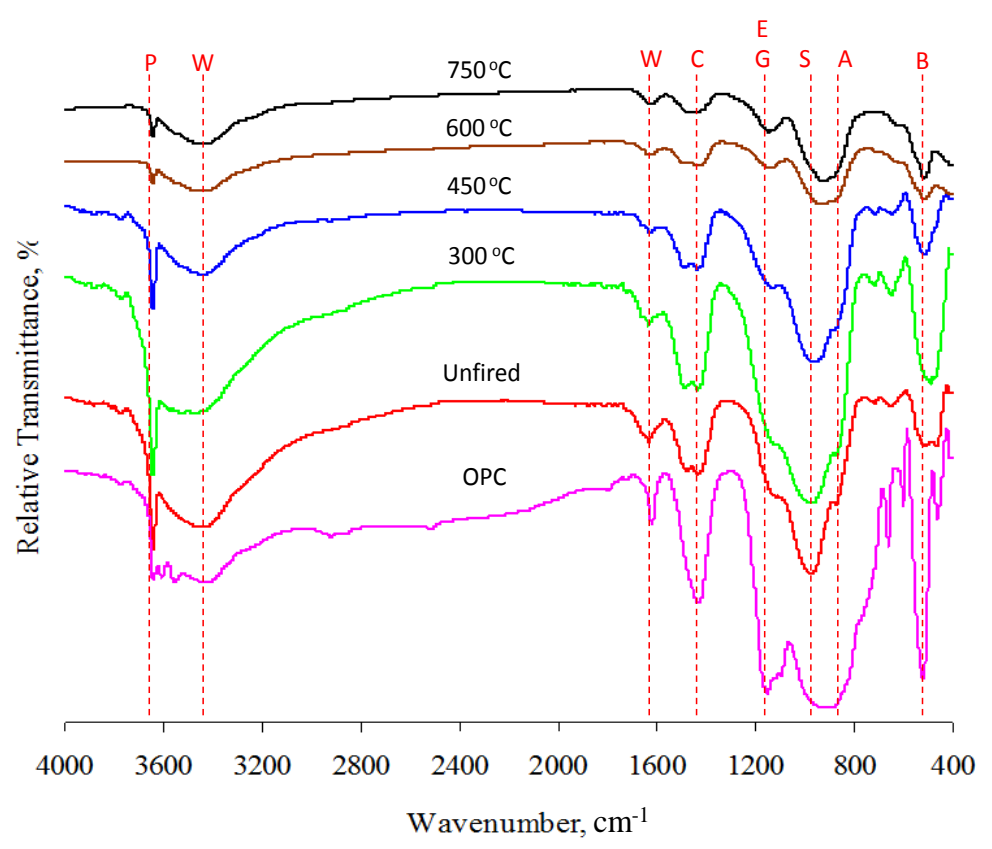

Figure 6. FTIR spectra of cement pastes fired at $300^{\circ} \mathrm{C}-750^{\circ} \mathrm{C}$. (where: A alite, $\mathrm{B}$ belite, $\mathrm{C}$ calcite, $\mathrm{E}$ ettringite, $\mathrm{G}$ gypsum, $\mathrm{P}$ portlandite, $\mathrm{W}$ water), (vs very strong, s strong, $\mathrm{m}$ medium, w weak, - not found).

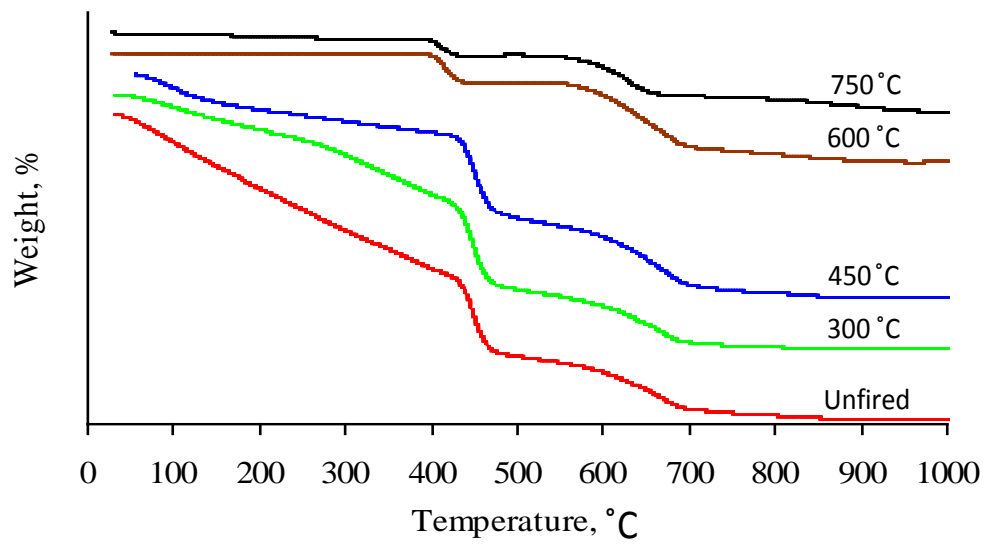

Figure 7. TGA thermograms of cement pastes fired at $300^{\circ} \mathrm{C}-750^{\circ} \mathrm{C}$.

percentage of residual portlandite and calcium hydrates in cement pastes fired at $300^{\circ} \mathrm{C}-750^{\circ} \mathrm{C}$ are given in Table 2 . These results give a crucial picture about the decomposition of amorphous calcium silicate hydrates which can not be detected by XRD analysis.

The percentage of portlandite that was estimated for the unfired cement paste (28.49\%) nearly agrees with that typically reported in the literature (i.e. portlandite occupies $20 \%-25 \%$ of the hydrated cement paste) [57]. With rising temperature up to $300^{\circ} \mathrm{C}$, the percentage of portlandite slightly increases due to hydration of the OPC grains which was encouraged under the hydrothermal condition. Above $300^{\circ} \mathrm{C}$, the percentage of portlandite slightly diminishes due to dehydration of portlandite to lime. Whereas above $450^{\circ} \mathrm{C}$, the percentage of 
Table 1. Relative intensity of characteristic absorption bands given in Figure 6.

\begin{tabular}{ccccccccc}
\hline \multirow{2}{*}{ Band, $\mathrm{cm}^{-1}$} & Phase & \multicolumn{7}{c}{ Relative intensity } \\
\cline { 3 - 7 } & & $\mathrm{OPC}$ & Unfired & $300^{\circ} \mathrm{C}$ & $450^{\circ} \mathrm{C}$ & $600^{\circ} \mathrm{C}$ & $750^{\circ} \mathrm{C}$ & Reference \\
\hline 518 & $\mathrm{C}_{2} \mathrm{~S}(\mathrm{O}-\mathrm{Si}-\mathrm{O})$ & $\mathrm{Vs}$ & $\mathrm{W}$ & $\mathrm{s}$ & $\mathrm{s}$ & $\mathrm{s}$ & $\mathrm{s}$ & {$[50][51]$} \\
937 & $\mathrm{C}_{3} \mathrm{~S}(\mathrm{Si}-\mathrm{O})$ & $\mathrm{Vs}$ & $\mathrm{W}$ & $\mathrm{m}$ & $\mathrm{m}$ & $\mathrm{s}$ & $\mathrm{s}$ & {$[50][51]$} \\
975 & $\mathrm{C}-\mathrm{S}-\mathrm{H}(\mathrm{O}-\mathrm{Si}-\mathrm{O})$ & - & $\mathrm{Vs}$ & $\mathrm{s}$ & $\mathrm{m}$ & - & - & {$[50]$} \\
1115 & Ettringite $\left(\mathrm{SO}_{4}^{2-}\right)$ & - & $\mathrm{M}$ & $\mathrm{m}$ & $\mathrm{m}$ & $\mathrm{m}$ & $\mathrm{m}$ & {$[49]$} \\
1144 & Gypsum $\left(\mathrm{SO}_{4}^{2-}\right)$ & $\mathrm{Vs}$ & - & - & - & - & - & {$[49]$} \\
1432 & Calcite $\left(\mathrm{CO}_{3}^{2-}\right)$ & $\mathrm{Vs}$ & $\mathrm{M}$ & $\mathrm{s}$ & $\mathrm{m}$ & $\mathrm{m}$ & $\mathrm{w}$ & {$[52]$} \\
1637,3455 & Free water $\left(\mathrm{OH}^{-}\right)$ & - & $\mathrm{S}$ & $\mathrm{vs}$ & $\mathrm{m}$ & $\mathrm{w}$ & $\mathrm{w}$ & {$[53]$} \\
3642 & Portlandite $\left(\mathrm{OH}^{-}\right)$ & $\mathrm{vw}$ & $\mathrm{S}$ & $\mathrm{vs}$ & $\mathrm{m}$ & $\mathrm{w}$ & $\mathrm{w}$ & {$[50]$} \\
\hline
\end{tabular}

Table 2. The relative percentages of residual calcium hydrates and portlandite in cement pastes fired at $300^{\circ} \mathrm{C}-750^{\circ} \mathrm{C}$.

\begin{tabular}{ccccc}
\hline Unfired & \multicolumn{2}{c}{ Calcium hydrates } & \multicolumn{2}{c}{ Portlandite } \\
\hline Sample & Mass change, \% & Decomposition percent, \% & Mass change, \% & Percent, \% \\
\hline Unfired & 5.13 & - & 6.93 & 28.49 \\
$300^{\circ} \mathrm{C}$ & 2.72 & 46.98 & 7.15 & 29.39 \\
$450^{\circ} \mathrm{C}$ & 2.38 & 53.61 & 5.05 & 20.76 \\
$600^{\circ} \mathrm{C}$ & 0.58 & 88.69 & 1.93 & 7.93 \\
$750^{\circ} \mathrm{C}$ & 0.23 & 95.52 & 1.30 & 5.34 \\
\hline
\end{tabular}

portlandite sharply diminishes but does not fall to zero value in cement pastes that were fired at $600^{\circ} \mathrm{C}-750^{\circ} \mathrm{C}$ due to the partial rehydration of lime. The percentage of calcium hydrates was lowered to its half value with rising temperature up to $450^{\circ} \mathrm{C}$. A severe and complete loss of calcium hydrates content occurs when cement paste was subjected to $600^{\circ} \mathrm{C}$ and $750^{\circ} \mathrm{C}$ respectively. This confirms that the dehydration of calcium hydrates is a multi-step reaction because of its complex structure [28] and occurs over a wide range temperature (i.e. from $105^{\circ} \mathrm{C}$ to $1000^{\circ} \mathrm{C}$ ) [22] and [29]. According to Jennings, the C-S-H gel consists of many small globules with a disordered layered structure, hence, water molecules release over a wide range temperature [58].

Figure 3 illustrates the DTA thermograms of cement paste fired at $300^{\circ} \mathrm{C}$ $750^{\circ} \mathrm{C}$. DTA results are useful to justify the dehydration process of portlandite. The endothermic peak located at about $450^{\circ} \mathrm{C}$ in the case of unfired cement paste and that was fired at $300^{\circ} \mathrm{C}-450^{\circ} \mathrm{C}$ corresponds to the dehydration of the primary portlandite that forms during the hydration of cement in the case of unfired cement paste and remaining portlandite that present in cement paste fired up to $450^{\circ} \mathrm{C}$.

The endothermic peak of portlandite was shifted to lower temperature range (about $410^{\circ} \mathrm{C}$ ) in the case of cement pastes fired at $600^{\circ} \mathrm{C}-750^{\circ} \mathrm{C}$ corresponds to 
the dehydration of the secondary portlandite that forms as a result of the rehydration of lime in the case of cement pastes fired above $450^{\circ} \mathrm{C}$. This result agrees with the previous results which illustrate that portlandite formed during the rehydration of fired cement paste has an onset dehydration temperature lower than the original portlandite [25]. The environments and formation condition of the primary and secondary portlandite is quite different, accordingly, their rate of dehydration are not equal. The secondary portlandite dehydrates at lower temperatures range may be due to the critical condition in which it forms which affect its surface area and particle size. The experimental results confirm that the decomposition of hydrates is affected by surface area and particle size [59].

Figure 8 illustrates the XRD patterns of cement pastes fired at $300^{\circ} \mathrm{C}-750^{\circ} \mathrm{C}$. The dominant crystalline phases that were detected in OPC are; alite, belite and calcite. The dominant crystalline phases that were detected in the unfired cement paste are calcite filler and portlandite arising from the hydration process as well as small proportions of the unhydrated alite and belite. XRD patterns comprise some changes in the phase compositions of cement paste with rising temperature. The proportion of portlandite diminishes above $450^{\circ} \mathrm{C}$ [60]. A significant proportion of belite and alite appears at $450^{\circ} \mathrm{C}$ and progressively increases at $600^{\circ} \mathrm{C}$ and $750^{\circ} \mathrm{C}$. This proves that the decomposition of C-S-H reaches a significant rate at $450^{\circ} \mathrm{C}$ and enhances with rising temperature [24]. This result agrees with FTIR and DTA results. According to Peng et al., it is difficult to differentiate between the peaks of $\mathrm{C}_{2} \mathrm{~S}$ and $\mathrm{C}_{3} \mathrm{~S}$ in XRD diagrams of cement pastes exposed to high temperatures. Hence, peaks of $\mathrm{C}_{2} \mathrm{~S}$ and $\mathrm{C}_{3} \mathrm{~S}$ can be used to

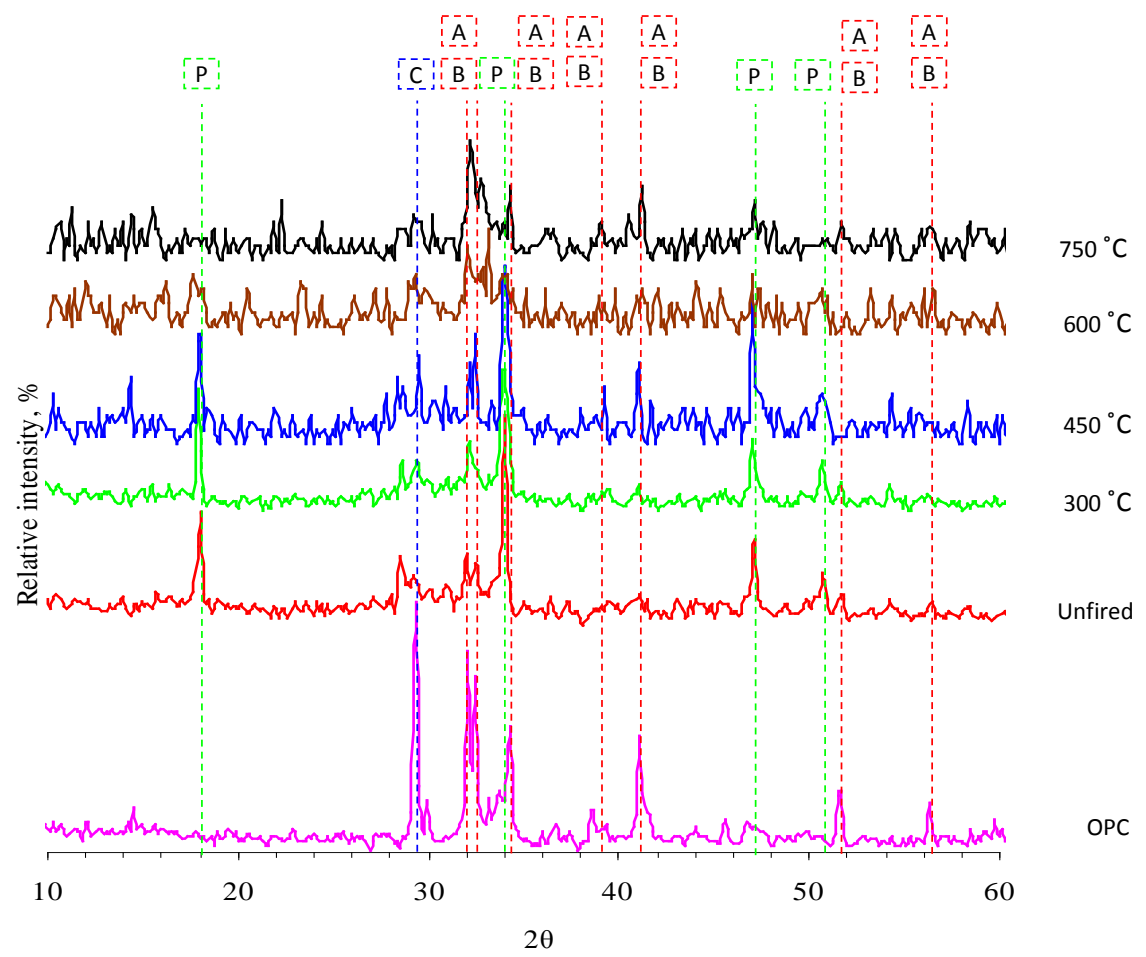

Figure 8. XRD patterns of cement pastes fired at $300^{\circ} \mathrm{C}-750^{\circ} \mathrm{C}$. (A alite, B belite, $\mathrm{C}$ calcite and $\mathrm{P}$ portlandite). 
represent both of them [13]. Figure 9 illustrates the SEM micrographs of cement paste fired at $300^{\circ} \mathrm{C}-750^{\circ} \mathrm{C}$. The results monitor the change in microstructure and phase compositions due to the hydration of OPC and the dehydration of cement paste fired at $300^{\circ} \mathrm{C}-750^{\circ} \mathrm{C}$. The micrograph of unfired cement shows OPC grains loaded with the hexagonal portlandite plates [61] and amorphous $\mathrm{C}-\mathrm{S}-\mathrm{H}$ formed during hydration of OPC. The microstructure of cement paste that was fired at $300^{\circ} \mathrm{C}$ has not changed significantly. Whereas, some of unhydrated cement grains and residues of hexagonal portlandite plates appear in the microstructure of cement paste that was fired at $450^{\circ} \mathrm{C}$. The micrograph of cement paste that was fired at $600^{\circ} \mathrm{C}$ shows the presence of distorted cubic calcite crystals [62]. The micrograph of cement paste that was fired at $750^{\circ} \mathrm{C}$ may show the presence of dehydration products. Accordingly, the decomposition of C-S-H significantly starts at $450^{\circ} \mathrm{C}$ and progresses with rising temperature.

Figure 10 illustrates the crack propagation in cement paste fired at $300^{\circ} \mathrm{C}$ $750^{\circ} \mathrm{C}$. Minor cracks (about $0.1 \mathrm{~mm}$ in width) appeared on the surface of cement paste that was fired at $300^{\circ} \mathrm{C}$. The cracks widen and deepen with rising
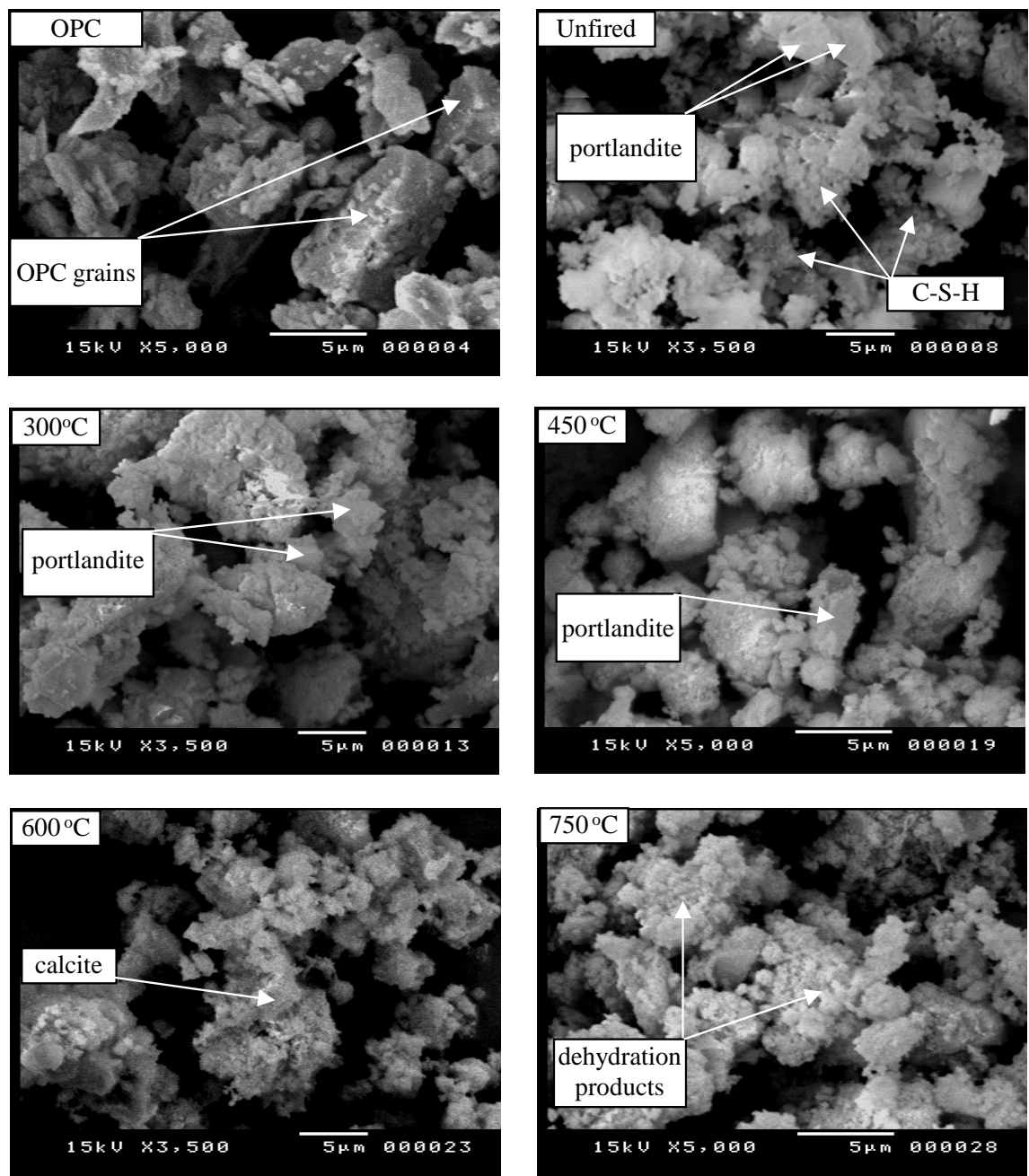

Figure 9. SEM micrographs of cement pastes fired at $300^{\circ} \mathrm{C}-750^{\circ} \mathrm{C}$. 

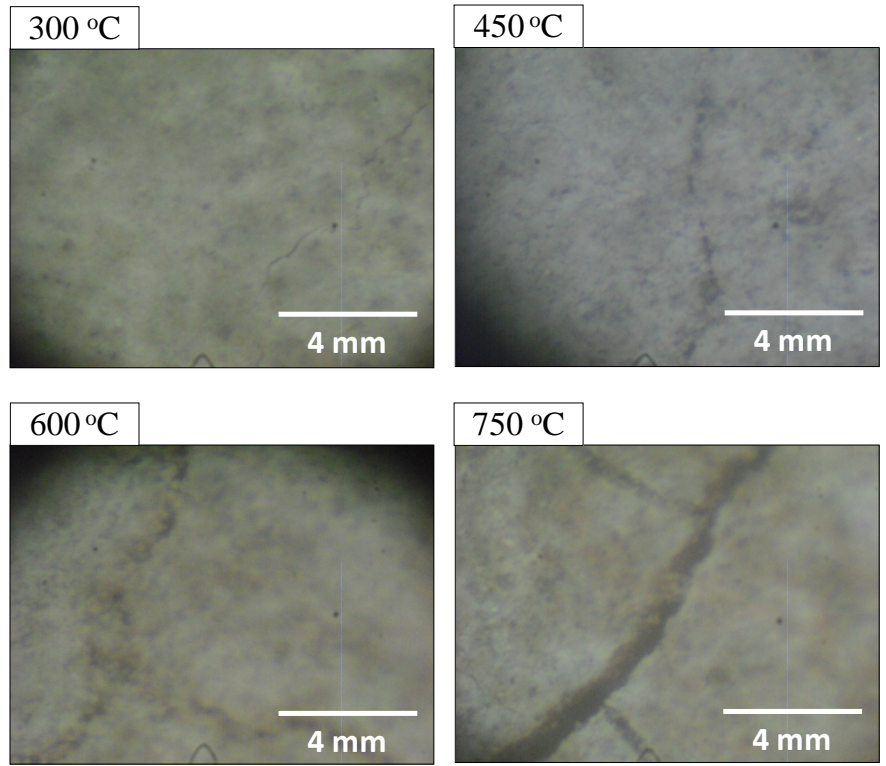

Figure 10. Crack propagation in cement paste fired at $300^{\circ} \mathrm{C}-750^{\circ} \mathrm{C}$.

temperature. Thin shallow linear superficial cracks (about $0.4 \mathrm{~mm}$ in width) appeared on the surface of cement paste that was fired at $450^{\circ} \mathrm{C}$. Thick grid-like deep cracks (about $0.8 \mathrm{~mm}$ in width) appeared on the surface of cement paste that was fired at $750^{\circ} \mathrm{C}$. The cracks form as a result of the following factors; 1) the internal pore pressure caused by water vapor that was accumulated after the dehydration of calcium hydrates in case of relatively low permeable cement paste accompanied by loss of mechanical strength, 2) the thermal shock that arises as a result of cooling of the heated cement paste, 3) the rehydration of lime that is accompanied by a significant volume increase [63].

\section{Conclusions}

FTIR, XRD, TGA/DTA and SEM techniques were used to monitor the microstructural and compositional changes within cement paste induced with rising temperature. Accordingly, the main conclusions are:

1) The microstructure of cement paste that was fired at $300^{\circ} \mathrm{C}$ has not changed significantly.

2) A negligible and limited strength loss was observed before $450^{\circ} \mathrm{C}$ attributed to the dehydration of $\mathrm{C}-\mathrm{S}-\mathrm{H}$, ettringite and calcium aluminate hydrates.

3) $450^{\circ} \mathrm{C}$ is a critical temperature in the thermal damage history of cement paste, around which the percentage of portlandite decreases due to its dehydration and the percentage of calcium hydrates was lowered to its half value.

4) Beyond $450^{\circ} \mathrm{C}$, the percentage of portlandite sharply diminishes and decomposition of C-S- $\mathrm{H}$ into $\mathrm{C}_{2} \mathrm{~S}$ and $\mathrm{C}_{3} \mathrm{~S}$ markedly progresses until complete loss of calcium hydrates content occurs at $750^{\circ} \mathrm{C}$.

5) These deleterious changes in the composition of cement paste are accompanied by an increase of the total porosity, severe loss in mechanical strength 
and propagation of harmful cracks.

6) The thermal shock that arises as a result of cooling of the heated cement paste and the rehydration of lime that is accompanied by a significant volume increase enhance the propagation of harmful cracks.

\section{References}

[1] Poon, C.S., Azhar, S., Anson, M. and Wong, Y.L. (2003) Performance of Metakaolin Concrete at Elevated Temperatures. Cement and Concrete Composites, 25, 83.

[2] Khoury, G.A. (1992) Compressive Strength of Concrete at High Temperatures: Reassessment. Magazine of Concrete Research, 44, 291. https://doi.org/10.1680/macr.1992.44.161.291

[3] Jhang, K.Y. (2009) Non Linear Ultrasonic Techniques for Non Destructive Assessment of Micro Damage in Material: A Review. International Journal of Precision Engineering Manufacturing, 10, 123. https://doi.org/10.1007/s12541-009-0019-y

[4] Park, S.J., Yim, H.J. and Kwak, H.G. (2014) Non Linear Resonance Vibration Method to Estimate the Damage Level on Heat-Exposed Concrete. Fire Safety Journal, $69,36$.

[5] Netinger, I., Varevac, D., Bjegovic, D. and Moric, D. (2013) Effect of High Temperature on Properties of Steel Slag Aggregate Concrete. Fire Safety Journal, 59, 1.

[6] Ezziane, M., Kadri, T., Molez, L., Jauberthie, R. and Belhacen, A. (2015) High Temperature Behavior of Polypropylene Fibers Reinforced Mortars. Fire Safety Journal, $71,324$.

[7] Ergun, A., Kurklu G., Baspinar, M.S. and Mansour, M.Y. (2013) The Effect of Cement Dosage on Mechanical Properties of Concrete Exposed to High Temperatures. Fire Safety Journal, 55, 160.

[8] Reddy, D.V., Sobhan, K., Liu, L. and Young Jr, J.D. (2015) Size Effect on Fire Resistance of Structural Concrete. Engineering Structures, 99, 468.

[9] Xiao, J., Li, Z., Xie, Q. and Shen, L. (2016) Effect of Strain Rate on Compressive Behavior of High-Strength Concrete after Exposure to Elevated Temperatures. Fire Safety Journal, 83, 25.

[10] Kontogeorgos, D.A., Semitelos, G.K., Mandilaras, I.D. and Founti, M.A. (2016) Experimental Investigation of the Fire Resistance of Multi-Layer Drywall Systems Incorporating Vacuum Insulation Panels and Phase Change Materials. Fire Safety Journal, 81, 8 .

[11] Wang, H.Y. (2008) The Effects of Elevated Temperature on Cement Paste Containing GGBFS. Cement and Concrete Composites, 30, 992.

[12] Alonso, C. and Fernandez, L. (2004) Dehydration and Rehydration Processes of Cement Paste Exposed to High Temperature Environments, Materials Science, 39, 3015. https://doi.org/10.1023/B:JMSC.0000025827.65956.18

[13] Peng, G.F. and Huang, Z.S. (2008) Change in Microstructure of Hardened Cement Paste Subjected to Elevated Temperatures. Construction and Building Materials, 22, 593.

[14] Ai, H., Young, J.F. and Scherer, G.W. (2001) Thermal Expansion Kinetics: Method to Measure Permeability of Cementitious Materials: II, Application to Hardened Cement Pastes. Journal of the American Ceramic Society, 84, 385. https://doi.org/10.1111/j.1151-2916.2001.tb00666.x

[15] Liu, X., Ye, G., De Schutter, G., Yuan, Y. and Taerwe, L. (2008) On the Mechanism 
of Polypropylene Fibres in Preventing Fire Spalling in Self-Compacting and High-Performance Cement Paste. Cement and Concrete Research, 38, 487.

[16] Xu, Y., Wong, Y.L., Poon, C.S. and Anson, M. (2003) Influence of PFA on Cracking of Concrete and Cement Paste after Exposure to High Temperatures. Cement and Concrete Research, 33, 2009.

[17] Heikal, M. (2000) Effect of Temperature on the Physico-Mechanical and Mineralogical Properties of Homra pozzolanic Cement Pastes. Cement and Concrete Research, 30, 1835.

[18] Morsy, M.M., Shebl, S.S. and Rashad, A.M. (2008) Effect of Fire on Microstructure and Mechanical Properties of Blended Cement Pastes Containing MK and SF. ASIAN Journal of Civil Engineering (Building and Housing), 9, 93.

[19] Rashad, A.M. and Zeedan, S.R. (2012) A Preliminary Study of Blended Pastes of Cement and Quartz Powder under the Effect of Elevated Temperature. Construction and Building Materials, 29, 672.

[20] El-Didamony, H., Abd El-Rahman, E. and Osman, R.M. (2012) Fire Resistance of Fired Clay Bricks-Fly Ash Composite Cement Pastes. Ceramics International, 38, 201.

[21] Morsy, M.S., Galal, A.F. and Abo-EI-Enein, S.A. (1998) Effect of Temperature on Phase Composition and Microstructure of Artificial Pozzolana-Cement Pastes Containing Burnt Kaolinite Clay. Cement and Concrete Research, 28, 1157.

[22] Tantawy, M.A., El-Roudi, A.M., Abdalla, E.M. and Abdelzaher, M.A. (2013) Fire Resistance of Sewage Sludge Ash Blended Cement Pastes. Journal of Engineering.

[23] Stepkowska, E.T., Blanes, J.M., Franco, F., Real, C. and Pérez-Rodriguez, J.L. (2004) Phase Transformation on Heating of an Aged Cement Paste. Thermochimica Acta, $420,79$.

[24] Heikal, M. (2006) Effect of Temperature on the Structure and Strength Properties of Cement Pastes Containing Fly Ash Alone or in Combination with Limestone. $\mathrm{Ce}$ ramics Silikaty, 50, 167.

[25] Alarcon-Ruiz, L., Platret, G., Massieu, E. and Ehrlacher, A. (2005) The Use of Thermal Analysis in Assessing the Effect of Temperature on a Cement Paste. $\mathrm{Ce}$ ment and Concrete Research, 35, 609.

[26] Ukrainczyk, N., Ukrainczyk, M., Šipušić, J. and Matusinović, T. (2006) XRD and TGA Investigation of Hardened Cement Paste Degradation. 11 th Conference on Materials, Processes, Friction and Wear, Vela Luka.

[27] Ye, G., Liu, X., De Schutter, G., Taerwe, L. and Vandevelde, P. (2007) Phase Distribution and Microstructural Changes of Self-Compacting Cement Paste at Elevated Temperature. Cement and Concrete Research, 37, 978.

[28] Zhang, Q. and Ye, G. (2012) Dehydration Kinetics of Portland Cement Paste at High Temperature. Journal of Thermal Analysis and Calorimetry, 110, 153. https://doi.org/10.1007/s10973-012-2303-9

[29] Khoury, G.A., Majorana, C.E., Pesavento, F. and Schrefler, B.A. (2002) Modeling of Heated Concrete. Magazine of Concrete Research, 54, 77.

[30] Rehsi, S.S. (1993) Portland Fly Ash Cement in Mineral Admixtures in Cement and Concrete. Edited by Ghosh, S.N., Sarkar, S.L., and Harsh, S., ABI Books, New Delhi, 158.

[31] Mendes, A., Sanjayan, J.G., Gates, W.P. and Collins, F. (2012) The Influence of Water Absorption and Porosity on the Deterioration of Cement Paste and Concrete Exposed to Elevated Temperatures, as in a Fire Event. Cement and Concrete Com- 
posites, 34, 1067.

[32] Maaroufi, M.A., Lecomte, A., Diliberto, C., Francy, O. and Brun, P. (2015) Thermo-Hydrous Behavior of Hardened Cement Paste Based on Calcium Aluminate Cement. European Ceramic Society, 35, 1637.

[33] Vysvaril, M., Bayer, P., Chroma, M. and Rovnanikova, P. (2014) Physico-Mechanical and Microstructural Properties of Rehydrated Blended Cement Pastes. Construction and Building Materials, 54, 413.

[34] Lin, W.M., Lin, T.D. and Powers-Couche, L.J. (1996) Microstructures of Fire Damaged Concrete. ACI Materials, 93, 199.

[35] Poon, C.S., Azhar, S., Anson, M. and Wong, Y. (2001) Strength and Durability Recovery of Fire Damaged Concrete after Post-Fire-Curing. Cement and Concrete Research, 30, 1307.

[36] Shui, Z., Xuan, D., Wan, H. and Cao, B. (2008) Rehydration Reactivity of Recycled Mortar from Concrete Waste Experienced to Thermal Treatment. Construction and Building Materials, 22, 1723.

[37] Serpell, R. and Lopez, M. (2013) Reactivated Cementitious Materials from Hydrated Cement Paste Wastes. Cement and Concrete Composites, 39, 104.

[38] ASTM Designation (1983) C109-80, Standard Test Methods for Compressive Strength of Hydraulic Cements. Annual Book of ASTM Standards.

[39] Kumar, S. and Kameswara Rao, C.V.S. (1995) Strength Loss in Concrete Due to Varying Sulfate Exposures. Cement and Concrete Research, 25, 57.

[40] Pavlik, J., Tydlitat, V., Cerny, R., Klecka, T., Bouska, P. and Rovnanikova, P. (2003) Application of a Microwave Impulse Technique to the Measurement of Free Water Content in Early Hydration Stages of Cement Paste. Cement and Concrete Research, 33, 93.

[41] Gennaro, R., Cappelletti, P., Cerri, G., Gennaro, M., Dondi, M. and Langella, A. (2004) Zeolitic Tuffs as Raw Materials for Lightweight Aggregates. Applied Clay Science, 25, 71 .

[42] Copeland, L.E. and Hayes, T.C. (1956) Porosity of Hardened Portland Cement Pastes. American Concrete Institute, Materials, 27, 633.

[43] ISO (1983) 5018:1983, Determination of True Density of Refractory and Other Raw Materials.

[44] Földvári, M. (2011) Handbook of Thermogravimetric System of Minerals and Its Use in Geological Practice. Geological Institute of Hungary, Budapest.

[45] Dolado, J.S., Griebe, M. and Hamaekers, J. (2007) A Molecular Dynamic Study of Cementitious Calcium Silicate Hydrate (C-S-H) Gels. Journal of the American Ceramics Society, 90, 3938.

[46] Zhang, B. (2011) Effects of Moisture Evaporation (Weight Loss) on Fracture Properties of High Performance Concrete Subjected to High Temperatures. Fire Safety Journal, 46, 543.

[47] Saad, M., Abo-El-Enein, S.A., Hanna, G.B. and Kotkata, M.F. (1996) Effect of Temperature on Physical and Mechanical Properties of Concrete Containing Silica Fume. Cement and Concrete Research, 26, 669.

[48] Rashad, A.M., Sadek, D.M. and Hassan, H.A. (2016) An Investigation on Blast-Furnace Slag as Fine Aggregate in Alkali Activated Slag Mortars Subjected to Elevated Temperatures. Journal of Cleaner Production, 112, 1086.

[49] Alonso, M.M., Palacios, M. and Puertas, F. (2013) Effect of Polycarboxylate-Ether 
Admixtures on Calcium Aluminate Cement Pastes. Part 2: Hydration Studies. Industrial and Engineering Chemistry Research, 52, 17330. https://doi.org/10.1021/ie401616f

[50] Matossi, F. (1949) Vibration Frequencies and Binding Forces in Some Silicate Groups. Journal of Chemical Physics, 17, 679. https://doi.org/10.1063/1.1747369

[51] Bakharev, T. (2005) Geopolymeric Materials Prepared using Class F Fly Ash and Elevated Temperature Curing. Cement and Concrete Research, 35, 1224.

[52] Gadsden, J.A. (1975) Infrared Spectra of Minerals and Related Inorganic Compounds. 3rd Edition, Butterworths, London.

[53] Liew, Y.M., Kamarudin, H., Mustafa Al Bakri, A.M., Luqman, M., Khairul Nizar, I., Ruzaidi, C.M. and Heah, C.Y. (2012) Processing and Characterization of Calcined Kaolin Cement Powder. Construction and Building Materials, 30, 794.

[54] Vedalakshmi, R., Sundara Raj, A., Srinivasan, S. and Ganesh Babu, K. (2003) Quantification of Hydrated Cement Products of Blended Cements in Low and Medium Strength Concrete using TG and DTA Technique. Thermochimica Acta, 407, 49.

[55] Mitchell, L.D. and Margeson, J.C. (2006) The Effect of Solvents on C-S-H as Determined by Thermal Analysis. Journal of Thermal Analysis and Calorimetry, 86, 591.

[56] European Committee for Standardization (2000) Cement: Common Cements. PrEN 197-1, CEN/TC51/WG 6 rev., Final Draft.

[57] Mobasher, B. (2002) Hydration, Best 50 Minutes, Undergraduate Faculty Development. NSF Center for Advanced Cement Based Materials, Northwestern University.

[58] Jennings, H.M. (2008) Refinements to Colloid Model of C-S-H in Cement: CM-II. Cement and Concrete Research, 38, 275.

[59] Boynton, R.S. (1980) Chemistry and Technology of Lime and Limestone. John Wiley and Sons, New York.

[60] Platret, G. (2002) Monitoring the Hydration of Cement and the Evolution of Solid Phases in Concrete by Thermal Analysis. Microstructural Characteristics and Properties Related to the Durability of Concrete. Methods of Measuring and Testing Laboratory, Test Methods No. 58, Central Laboratory of Bridges and Roads, Paris.

[61] Mehta, P.K. (1986) Concrete, Structure, Properties and Materials. Prentice-Hall, Englewood Cliffs, 450.

[62] Wang, H., Alfredsson, V., Tropsch, J., Ettl, R. and Nylander, T. (2013) Formation of CaCO3 Deposits on Hard Surfaces: Effect of Bulk Solution Conditions and Surface Properties. ACS Applied Material Interfaces, 5, 4035. https://doi.org/10.1021/am401348v

[63] Petzold, A. and Rohr, M. (1970) Concrete for High Temperatures. Maclaren and Sons, London. 